\title{
'A STRANGER IN THE NAME OF JESUS': \\ EXPLORING COSMOPOLITAN ETHICS IN A UGANDAN CHRISTIAN CARE \\ COMMUNITY
}

Susan Wardell ${ }^{1}$

\begin{abstract}
This article uses the author's ethnographic case study of a Christian youth work community in Uganda to inform a discussion around the theoretical relationship between cosmopolitan ideologies and Christian care ethics. Fieldwork conducted among the youth workers of 'Moment of Truth Evangelistic Ministries' (мотем), in Kampala, Uganda, between 2012 and 2014 highlighted a moral obligation to care. Two points of similarity are shown between this and what is usually described as a cosmopolitan ethic. The first is the basis of care in an identification with an imagined moral community - a transcendent and global 'family of believers' - and the second is a care orientation to a universal recipient. I discuss orientations to strangers, neighbours, village-mates, and family, in order to explore the faith-based youth worker as an embedded moral subject; situated in both local and global moral worlds. The article argues against other authors that have suggested religious fundamentalism is diametrically opposed to a cosmopolitan sensibility, using the case study to elucidate the complex and intersecting ways that cosmopolitan and Christian subjectivities can be experienced in the contemporary religious modernity of Kampala.
\end{abstract}

Keywords: Care, morality, Christianity, cosmopolitanism, Uganda

\section{INTRODUCTION}

Become a practical empathetic person who is going to extend that love into a thing that they can touch and a thing they can see [...] because that is when they can realise that truly Jesus loves them: they can relate with you, they can know that someone is out there, that a stranger has shown up in the name of Jesus. (Pastor Raymond, Kampala, Uganda, Advice to youth workers, Dec 2013) 
The purpose of this article is to facilitate a discussion around the theoretical relationship between cosmopolitan ideologies and Christian care ethics, using the case study of a community of faith-based care workers in Kampala, Uganda. According to Kleinman, caregiving must be viewed as a moral act (2012). Moral experience, he goes on to argue, is 'always about practical engagements in a particular local world' $(2012,493)$. Scholarship premising the notion of care on this kind of geographically-rooted morality sits in interesting tension with the claims of contemporary cosmopolitan scholarship, namely that care can be enacted based on connections and identities fostered on a much broader, even global, scale. The tensions, limits, and possibilities of this expanded latitude of cosmopolitan care are examined directly by Appiah, in Cosmopolitanism: Ethics in a World of Strangers (2006). Appiah acknowledges the impossibility of connecting to the entire category of 'humankind' with the same 'warmth and power that comes from shared identity' as smaller or more immediate groupings (p.98). Yet the human capacity for building solidarity with strangers can, he argues, take a central and valuable role in contemporary care ethics.

Quoted above, Pastor Raymond's description of the proper care orientation for faith-based youth workers emphasises the ability to embody care to strangers. In many ways this reflects what Appiah calls 'cosmopolitan.' However, Raymond does not identify as a cosmopolitan, but as a Christian. He works with a small interdenominational faith-based organisation called 'Moment of Truth Evangelistic Ministries' (мотем), which is based in Uganda's capital city of Kampala.

This article draws on ethnographic material from my 2012-2014 fieldwork with the youth workers of мотЕм, which included two focussed periods of fieldwork, of around six weeks each. During this time I worked as a mzungu (white/foreign) 'intern' in the largely indigenous organisation, living on site and participating in variety of different youth-work activities and events around the city. This provided opportunity for extensive participant observation, several focus groups (ranging in size from five to twenty-five), the collection of more than seventy surveys (at a large training event), combined with the use of reflexive fieldwork journaling, and qualitative analysis of a variety of visual, print, and digital artefacts. Forming the backbone of the analysis, were my twentythree in-depth, semi-structured interviews with youth workers associated with мотем - eighteen men, and five women (reflecting the gender bias evident within Kampalan youth work as a social field). I applied a narrative discourse approach to analysing these.

As an author I write from a position of intimate entanglement with my participants and their life worlds, being a (religious) insider, even while being a 
cultural outsider. I recognise that this has been a contested and overdetermined positionality for researchers in anthropology; a course well-worn already, in fact, by many great scholars in the anthropology of religion, from E. Evans-Pritchard, to Mary Douglas, to Victor and Edith Turner (Larsen 2014). More recently, discussions of the value of standpoint theory (Howell 2007), and methodological bracketing (Engelke 2002), have addressed this 'problem of belief' in varying ways. In this work I have drawn on standpoint theory, and utilised (alongside ethnographic data), auto-ethnographic reflections on my own experiences of the fluid links, the points of sameness and difference in the values and practices of Christian community/ies around the world.

There are two aspects of Christian care work which I will compare to a cosmopolitan experience. The first is the identification with an imagined moral community - a transcendent and global 'family of believers' - and the second is a care orientation to a universal recipient. The nuanced care practices and meanings I encountered in this community have led me to argue against other authors (such as Rapport and Stade 2007) who have portrayed Christianity and other 'fundamentalist' religious communities as essentially at odds with cosmopolitan ethics. I follow a line of argument that links caring obligations to caring identities, arguing that the practice of caregiving is rooted in a particular orientation to self, to others, and to the world. I use examples from my observations at мотем to illustrate several areas of convergence between the seemingly oppositional identities of a Christian as a citizen 'not of this world' (i.e., of nowhere, or nowhere earthly), and a Cosmopolitan as a citizen 'of the world' (i.e., of everywhere, or nowhere in particular). Through this lens I am able to explore the embodied negotiation of tensions between local and geographic commitments and connections, and the global, transcendent moral communities. Since my own analysis has focussed on care as part of vocational practice, I begin by situating мотЕм as an organisation within the wider social field of 'youth work', and against the scant academic literature which has focussed on this area of the non-profit sector.

\section{INTRODUCING MOMENT OF TRUTH}

A vibrant, cutting edge, outreach organization solely envisioned to share the love of Christ to the lost and hurting world, with a holistic approach. (МОтем banner 2013)

This is how мотем described themselves on a large banner doing doubleservice in masking a hole in the concrete wall in the tiny, one-room office they keep in the suburb of Rubaga. On the мотем Website, they specified that they 
are 'a registered non-denominational, evangelistic and faith-based charity; our outreach is to all, regardless of social class, colour, or race' (2014). Here and on the ground, мотем boasted a broad portfolio of projects, but with a primary focus on young people - understandable in a nation where over seventy-five per cent of the population are under thirty years of age (Christiansen 2011). They focus primarily on Kampala city; a boiling pot for the nation's ethnic diversity, with young people in particular gravitating there seeking education, or employment (against difficult odds). MOTEM was a small organisation, with no paid staff members, and no regular governmental, multinational, or NGO funding. Despite this, their reach throughout Kampalan tertiary campuses in particular was impressive; achieved through the efforts of volunteers, individual and irregular financial contributions, and the indefatigable passion of founder and Director Stephen Adundo Egesa, whose grinning face also beamed down from the banner, as well as from behind the desk where he (very occasionally) sat down in between a whirlwind programme of visits and talks around the city. Pastor Raymond was his righthand man, a faithful, founding member of the team, often found beside him at the desk, when not also out and about with suit and microphone.

The youth workers I observed, interviewed, and worked with at Мотем were zealous, ambitious, and relentlessly optimistic. They were also humble, dedicated, and generous. They understood themselves as having a moral obligation to care. But why, and for whom? These are the questions which Engster (2005) argues remain essential yet underdeveloped in the theory of care as a moral concept. Appiah, according to Jeffers (2013, 493), distinguishes between what emerged from 'the context of thick relationships to others with whom we share some sense of community and collective memory', which he calls 'ethical obligations', and what is established on the basis 'our thin relationship to each other as human beings deserving equal respect.' The latter is what he classes as a 'moral obligation'. While his definition of the terms ethical and moral seem to be in reverse to Kleinman's ${ }^{2}$, both scholars acknowledge that experiences of enacting and embodying 'good' actions and emotions in real worlds can be informed by discourses relating to more than one level of sociality. The work of the мотем leaders with youth could be observed to contain all three of the aspects of care summarised by Engster (2005); supporting basic biological needs or sustaining life; assisting others to develop and sustain the capacity for participation in social life and pursuit of the 'good' (moral) life; and the relief of suffering or pain. The allocation of time to various tasks each day can be extremely varied, but it is broadly characterised by a 'redemptive' focus, and attentiveness to social lives, meanings, and contexts of individual wellbeing, 
which in turn leads to very locally specific forms of suffering that are addressed, and forms of good that are promoted.

Raymond was vocal about his belief that God had asked him to fulfil the call of the gospel by reaching out to young people. In this and many other diverse settings around the world, youth work is one way in which the Christian church fulfils its purpose and exercises its moral and social responsibility within society (Davies 2012, 148). However as a vocational field, youth work is a 'slippery' form of work to describe. Both an old field and a new one, its beginning can be traced to a volunteer movement in Europe in the last century with an interest in young people's 'moral hygiene': their education and socialisation towards upright citizenship (Sercombe 2004). Today (western-based) literature describes it being enacted as part of three main sectors; integrated services, the voluntary sector, and the faith-based sector. The retreat of state services under neoliberal reform has led to an increasing emphasis on voluntary and faith-based work for meeting the needs of disadvantaged and disenfranchised groups.

A small number of scholars have provided sensitive ethnographic portraits of Christian social work which, while not specific to youth work, have usefully examined the complex layers of identity, discourse, practice and social relationships which surround and support faith-based-activism. Elisha's study of Evangelical activists in Tennessee describes the active negotiation of the troubling discursive tensions between 'accountability' and 'grace' in the local church (2008). Wuthnow's body of work $(1995,2012)$ on moral aspects of kindness and compassion among young church-based volunteers in contemporary America illustrates the relationship between individual experience, identity formation, and practice. Allahyari's (2000) ethnographic comparison of volunteers across several different North American charities tackles the task of drawing out the theoretical links between selfhood and subjectivities and particular organisational discourses of morality and care. Muehlebach's (2012) ethnography of volunteerism in Italy, draws sharp and convincing connections between the particular values of Catholic-Christian care, and those of neoliberal moral economies. Her book provides a nuanced examination of the ways these two ethical frameworks converge and articulate in practice. These exist as part of scholarship around care labour, vocational identity, and professional wellbeing, which are more often applied to secular fields. The bias towards studies grounded in western nations is also clear. In this chapter I offer a case study of care ethics in a less-studied region of the world, and in one where the local and the global intersect in terms of both implicit cultural values, and more explicit religious ones. 
Christianity is a global faith system, reliant on symbolic structures and metanarratives shared across national borders and maintained through the previous two millenia via scripture, doctrine, ritual, and tradition. Present in nearly every nation of the world at this moment in history, a rich body of ethnographic material nonetheless reveals that it is deeply diverse in its many local articulations and embodiments. Because of this I do not claim to discuss the Christian care ethic, but $a$ Christian care ethic, as observed in one particular locale, with connection to but also distinguishable from the care ethic of other Christian communities.

Like anthropology itself, Christianity is a 'contact zone' in that it creates opportunities for encounters with the Other. Christianity has long fostered a 'travelling culture' of missionaries and evangelists. Ambitiously global in scope from its outset, the New Testament scriptures emphasise taking the good news of the gospel 'to the ends of the earth'. In contemporary settings Christian nongovernmental or charitable bodies, and international denominational networks provide the means for financial, educational, and human resources to move across borders continually. As such they set up both fleeting and established moments of cross-cultural encounter, and contemporary religious adherents must engage with both global Christian meanings as well as complex national and local ones.

The Christian church is globalised in many senses of the word (Bielo 2007; Coleman 2000; Csordas 2007; Meyer 2004; Robbins 2003a). However being 'global' is not necessarily synonymous with being cosmopolitan. A closer examination of attitudes and ethics is needed. Some relevant points are made by Josephides (2010), who observed that the early Christian ecclesia was essentially a community of mobile foreigners. In a letter to the early Galation church, for example, Paul declares 'There is neither Jew nor Gentile, neither slave nor free, nor is there male and female, for you are all one in Christ Jesus' (Galation 3:28, NIV Translation). Here he expresses the Christian identity as establishing a sense of belonging that transcends national boundaries, that changes foreigners into brothers; an idea that Bennington (1997) observes has an obvious connection with Kant's own early development of the notion of cosmopolitanism, centred around an identity in which one declares citizenship not to any particular nation but to 'the world'. Josephides $(2010,392)$ also affirms that as 'An original transnational community, Christianity carried a cosmopolitan message, but its mobility was assimilative. So how do these principles articulate in the contemporary religious modernity of Uganda, 2,00o years later? A closer 
comparison of both more ethnographic studies of Christian community, and more contemporary scholarly explorations of cosmopolitan ethics, is needed.

\section{GLOBAL FAMILY: A TRANSCENDENT MORAL COMMUNITY}

Anderson's notion of the 'imagined community' was originally applied to nationalism, but more recently Beck (2011) has repurposed and extended it to describe a global imagined community. This global community, he argues, is a formation of belonging and identification specific to the politico-economic forces of modernity. It is also a fundamental part of cosmopolitanism. However it is not unique to cosmopolitanism, for Christianity, too, has and continues to have a strong sense of global community that is constituted powerfully, as I shall explain, through performative language, metaphor, and narrative. This is in fact never more evident than when one is moving across borders. For example, from the moment my husband and I stepped off the plane we became 'Brother Andrew' and 'Sister Susan'. We accumulated instantly upon introduction, a great number of other brothers and sisters too. What is more, although a strong preoccupation with democratic order was observable among even the most fledging, under-resourced Christian groups and organisations we encountered in Kampala, the titles of 'brother' and 'sister' were consistently employed. The intention was to indicate a warmth, openness, and egalitarianism of relations; to arouse the moral imagination, as Appiah (2006) has put it. Furthermore, many times throughout our visit, people were introduced with the special explanation that he or she was 'part of us' at мотем. When we left, my husband and I were similarly thanked by many мотем staff and members for 'being part of us'. Such words were intended to indicate a closeness of relationship, and a mutuality of shared identity; and indeed not only to indicate, but to function as performative utterances (Austin 1962) that in and of themselves did the work of inviting, invoking, binding together. However, it is important to acknowledge that this process of collective subjectification began earlier, not at the moment of meeting in person, but at the moment when each person joins the invisible and transcendent whole of the 'Christian church' - the moment of conversion.

Conversion formed a central part of the narrative identity of the youth workers I spoke with in Kampala. Officially 'becoming' a youth leader in Kampala begins with the election to a certain position, or the beginning of one's own ministry, allowing the right to the title of 'youth worker', 'youth leader', 'papa' or otherwise. However, the stories of calling ${ }^{3}$ that were stable tropes of both public testimony and private discourse, centred around the event of salvation as the primary moment of subject formation. I noted that among many possible idioms for conversion, one of the most common vernaculars among Kampalan 
youth leaders was 'joining Christ'. This is a pertinent linguistic indicator of the relationality inherent in contemporary Evangelistic Christianity, i.e., being in an intimate relationship with a personal God (Luhrmann 2004, 519). It also notably indicates the locus of the transformed identity of the new believer within a collective identity centred not on a geographically specific community of believers, but an international, intertemporal 'body' of Christ.

The identity and ideology of young Christian born-agains ${ }^{4}$ is specific to urban Kampala (Gusman 2009, 2013). Several distinct waves of Pentecostalism in Uganda have contributed to its establishment, becoming a highly visible in the city in particular. Kampala is a melting pot for numerous deeply-rooted ethnic identities which have been the divisive points for serious internal political and military conflict in the past. In such a setting, one of the most striking absences in the interviews, conversations and observations I made of the Mотем workers was the reference to tribe or ethnicity. While more pointed and informal conversations with key participants revealed a heightened (and humourously articulated) awareness of the stereotypes and tensions existing between many of Uganda's tribal groups, in terms of the practice of evangelical youth work, reference to these was excluded with a completeness that betrayed the deliberacy of their omission. I argue that it relates significantly to the effect of their new identities as 'believers' and new sense of belonging as part of the 'family of believers. This is a process that involves the transfer of their primary locus of identification from local and ethnic identities onto spiritual ones rooted in global, transcendent Christian communities.

There are some very specific implications for the re-alignment of local identities to global ones, within the current political climate of Uganda. Specifically, on a national scale, in their emphasis on belonging to a new spiritual group, the 'born again', over biological belonging, Pentecostals answer many of the ethnic and sectarian tensions between the Catholic and Anglican (Church of Uganda, or COU), that had earlier dominated Uganda's political history (Gusman 2013, Ward 2004). Furthermore, born-agains also shed another 'spoiled' identity as they take up their roles as Christian leaders. In Ugandan society young people are frequently associated with both moral and public health problems (Christiansen 2011), and systematically stigmatised and disempowered as a consequence. Charismatic conversation rituals provide a powerful cleaning experience for these (Wardell 2015). The narrative trope of 'a break with the past' is something that several authors (Christiansen 2011; Gusman 2013) have identified strongly in Ugandan Christianity. This was present in the calling stories of мОтЕм leaders which bore a common narrative structure focussing on separating old identities from new ones, and emphasising change and trans- 
formation. Not only communicative, but performative, these 'confession' style narratives, echo the style of reflexive exercise which Foucault (1988) asserted can be a potent tool for subject formation, in a way that is clearly deeply situated in the local context. In this way the very cosmopolitan process of identification with a global imagined community can be read here as emerging not only as an inevitable response to globalisation, but as a strategic response to a variety of locally-embedded discourses, divisions, and anxieties. Here, the universal does not encompass the Christian identity, but is rather promoted by and through it. These shifting subjectivities prescribed new ways of connecting and belonging to Others. This also changed the way obligations to care were conceived, in both their scope and focus.

DOES A TRANSCENDENT COMMUNITY OFFER UNIVERSAL CARE?

A number of authors have argued that the pillars of cosmopolitanism - attitudes of acceptance and respect, of the acknowledgment of the person as a person, of the intrinsic value of their uniqueness and difference at that moment in time - can come only from a standpoint of universal moral community (Appiah 2006; Christman 2010; Nussbaum 1996). The identities of the мотем leaders are rooted in a global moral community which echoes many of the tenets of cosmopolitan citizenship. This identity within, or identification with, a (global) community of brothers and sisters, I have established is the basis for a sense of calling that focuses on care, compassion, and empowerment as its central tenets (Wardell 2015). However, the global does not necessarily invoke the universal. Does the transcendent global community of Christendom constitute a universal kingdom? Are the metaphors of family capable of fostering the universal and cosmopolitan care outlook these authors describe? Pastor Raymond expressed that

Being a born again $[. .$.$] we are called to, to be a light unto the world$ [...] with that kind of assignment in the scripture that gives us a great commission to go out and preach the word it automatically makes you a leader because you are going out to meet people who are hurting, who are in pain, people who need someone to encourage them, and by the mere fact that you are doing that it automatically makes you a leader by default.

As Raymond's explanation typifies, what the мотем leaders usually referred to as having the deepest impact on their lives and their identities to draw them into their current roles, was 'the call on all believers' that they often hoped, prayed, and believed their entire generation would rise up in response to. This 
collective identification (the pronouns 'we' and 'us') of the youth leaders' identity leads to a more collective and generalised sense of calling to the care labours of youth work. Although they experienced the process of calling in specific and idiographic ways, the nature of the calling to which they felt drawn was the broader 'task' given to all believers: the task of caring, preaching, teaching, empowering, giving and serving others, which was non-optional; a command, not a request, as one leader put it. Universal therefore in its prescription of who should do the caring, was it also universal in prescribing who should be cared for?

In one sense, Christian theology does create a universal category of potential sameness and belonging - every person is a potential member, as all are eligible for the salvation (and transformation) that is universally offered through acceptance of Christ. On paper at least, no difference is too radical and no category of persons is excluded from this possibility of 'becoming' a Christian. However, complex social and individual factors mean that at the same time, not everyone has yet or will ever actually be interpellated as such. The call may technically, officially, be universal but both its application and uptake are far from it in the real world. Because of this, two fluid and impermanent but nonetheless powerful categories of alterity are created within the universal; the believer and the unbeliever, the saved and the unsaved. Even beyond Paul's declaration that there are 'no Jews or Gentiles in Christ', the more fundamental categories of 'in Christ' versus 'not in Christ' remain. These constitute an 'insider' and 'outsider' category, in an ontological if not social sense... which is to say that although they are understood as two different states of spiritual being, they may not function to exclude the 'outsiders' from the enactment of care, connection and sociality as one might expect.

Timothy was a friend of мотем, an attendee at many of their training events. At twenty-one years old he was engaged in outreach and leadership on his university campus, and had also founded his own mission organisation. Spry, gap-toothed, and zealous, he was eager to talk all about the work they were doing, and the trips they had taken. On one rainy morning in the office, with both great detail and great affect, he shared the various social problems of an area of Eastern Uganda he had just returned from. 'They're dying out there!' he railed, shaking his head, voice heavy with sorrow. His sense of connection, care, and responsibility for a generalised and imagined population, at some geographic distance from where we sat in the urban centre of Kampala, was striking. As Timothy moved from explaining about the economic pressures of the region, its demographic makeup, moral deficits, and epidemiological challenges, his compassion for the real and imagined 'strangers' of that place 
was palpable. Notably also, it was not faceless. His voice hushed as he shared a story about a specific little boy with leprosy, whom he had met there and was longing to help further. He had prayed for the boy and made promises to him regarding resources that he would send later. His care would stretch the distance between them, in both a practical and affective sense.

Werbner (2006) asserts that investment in 'morally and emotionally significant communities' such as families or ethnic groups is the necessary starting point from which cosmopolitan notions can emerge; including toleration, openness, the transcendence of ethnic difference, and the 'moral responsibility for and incorporation of the other' (Werbner 2006, 497). This is certainly strongly true of Christian youth workers, whose care practices assume a responsibility not only for the biological needs, social development, and suffering relief of those locally they feel called to care for, but also who experience the 'burden' of spiritual care and education for those whom they believe have their very souls at stake. In this sense, the greater urgency and burden of care is in fact in their attentions to those still outside of the 'family of God', the non-believers, who while representing the Other in a strong spiritual sense, are in many cases the primary objects of care and attention with every hope of eventual incorporation. It remains, as Josephides (2010) suggested of the very early seeds of the Christian church, an assimilative body, a 'hungry kingdom, which while open to engaging with all forms of difference, seeks eventually to transform, not by reshaping all aspects of identity (removing the 'Jew-ness' or 'Greek-ness', the ethnic identifications or national citizenships), but by shifting the primary subjectivity towards the shared one of 'believer', a transnational and transcendent one, even if not strictly universal.

As Jaye, Fitzgerald and George have noted (Introduction, this volume), the capacity to care for others can transcend politics of identity and difference, although never perfectly or permanently. мотем's mission statement is clear that their intention is to care for all, regardless of 'social class, color, or race' (мотем Website 2014). Indeed to summarise the argument thus far, by joining the (transcendent, global) community of Christ, Kampalan believers gain a new identity (from which to enact care labour) which, whilst not replacing, can temporarily 'trump' older, rooted forms of identity that are prescribed by geography and biology, thus shifting the nature of relationality among and between community members both physically present and 'imagined' or nonpresent. The 'body of Christ' and the 'family of God' are both significant framing devices used to achieve this and in the next section I extend this aspect of the discussion. In characterising the Christian faith community as a family, the мотем leaders established not only a sense of permanency and intimacy 
of belonging, but also of close mutual caring relations and obligations. The Christian youth workers this study involved often strongly evoked familial metaphors not only to describe, but (in training and teaching) to invoke a particular form of relationality between youth workers and those for whom they care, as I discuss now.

\section{LOCAL FAMILY: THE ADOPTION OF STRANGERS}

The family metaphor is necessarily complex; it has multiple points of performance and articulation within the мотем community. As I have discussed, in choosing to 'join Christ' young people in Uganda become part of a global (and transcendent) family of believers. However, family is a metaphor employed for both global and local moral communities. The мотем care workers take up not only the roles of 'brother' and 'sister' in an imagined, global, and transcendent family of believers, but also the roles of 'mother' and 'father' within fluid but locally-grounded networks of care. Both, I am arguing, take on cosmopolitan characteristics in their emphasis on obligations to strangers over (or at least alongside) more traditional points of connection.

It is standard in Kampalan youth fellowships in churches and school groups for the terms 'Mama' and 'Papa' to be used for leaders. These terms function both as formal titles for (elected) leadership positions, and more general terms of respect and endearment for those perceived as spiritual leaders. They play a significant role in structuring their subjectivities and identities as care workers. In Uganda and elsewhere the family remains the idealised social form of care (Colley 2001; Hockey and James 1993), despite real life ambiguities and abuses. It is particularly pertinent in a nation where poverty, low-life-expectancy, disease (particularly AIDS), conflict and displacement, and polygamy practices in rural areas have led to a high number of orphans, child-headed households, or convoluted extended family situations. These factors all contribute to rendering the stable nuclear family that is the Western media ideal, a relatively uncommon phenomenon. Furthermore, the younger generation of Christians commonly and publicly identify as 'spiritual orphans', due to a claimed sense of neglect from older generations of political and religious leaders (Christiansen 2011). In this vacuum it is indeed often 'age-mates' who step forward to provide social and emotional support. In this way, the мотем leaders' care work as 'mamas' and 'papas' is not only structured by global Christian ideologies and identities of care and the good carer, but with specific and locally situated versions of what that good carer looks like in that context. It is also an example of the way that the мотем leaders' membership in local symbolic communities shapes the way that global patterns of meaning and belief around care, Christianity, 
and the 'family of God' are experienced and conveyed, combining rather than cancelling-out their shared resonance.

Mama Suzan (real name, used with permission) of Uganda Christian University (UCU) was a strong example of the way that caring identities rooted in familial metaphors are internalised and practised. Suzan was the student board President of the University, as well as being a leader in the UCu fellowship and of a youth worship band at her church. She described these roles as often hinging around 'the task, the responsibility to be a Mother, even though you've never given birth biologically'. Suzan referred to having 'adopted' several of these girls who are only a year or two younger than her, having shared her food, money, family home, even her sleeping space. Like a mother she counselled them, fed them, and worried about them walking alone at night. Timothy also gave a parallel example of his relationship with a fellow classmate in primary school, whom he supported financially and emotionally for years. Timothy's friend still called him 'Daddy' today, even though they are the same age. Similarly, Suzan had many girls she calls her daughters, and who call her 'Mummy', who have come up to her directly to ask 'Can you be my Mother?' This represented a moment of interpellation into this specific caring role and its associated emotional forms. As she answered 'yes', recognising herself as such, she truly became 'Mummy' to them. This is not only a set of practical responsibilities, but a subjectivity requiring distinct forms of emotional labour. For example, Mama Suzan says when 'her girls' call her at midnight to say they are missing her she 'must be able to miss them too'. Compassion and empathy where 'you must feel for them, when this one comes crying, you must be in their shoes, you must lower yourself. You must understand, are essential affective orientations for this role.

In exploring volunteerism in Italy, Muehlebach's summarises Hume's seminal evaluation of the ethics of human societies, which denounced 'sympathy', as partial, inadequate because it favoured a person's immediate circle. She explains the theories arising around the need to 'artificially' extend this in the present day, using imagination 'to infer the sentiments of distant strangers' (Muehlebach 2012, 134). Richard and Rudnyckj (2009, 60) also emphasise 'the role of affect in enabling specific forms of global connection'. It is the transaction of affect which enables forms of connection at a distance, and shapes situated subjects in the process. In this case the cultivation and projection of empathy beyond the visible subject/object of care is done through the metaphor of family. мотем leaders like Suzan and Timothy are deeply invested in the families they are imagining and enacting. They regularly perform self-sacrificial care acts for people whom, outside of the Christian beliefs and communities they 
are committed to, would be no more than strangers. Their ability to utilise such powerfully performative metaphors to create a strong sense of connection and responsibility as the underpinnings for their care efforts, often in absence of traditional points of connection such as kinship, ethnic ties, or geographical background, bears a striking resemblance to the cosmopolitan care ethic that authors such as Werbner posit.

PRESENCE AND THE LOCAL

The embodied identity of the Christian youth worker as family member, whether parent or sibling, signifies proximity, presence, intimacy; a particular entanglement of emotional and practical support which is embedded in a shared lifeworld. The importance of 'presence' to caregiving is established in literature (Kleinman 2012, 1551). Even the quote from Pastor Raymond at the beginning of this chapter, while discussing care offered to strangers, emphasises the need for empathy to be expressed in ways that can be seen and felt. мотем's care labour is regionally focussed and geographically rooted. The day-to-day practice of care in such a setting relies on local knowledges, on a thick web of relationship and connection. While supported and facilitated by technology, in particular, cell phones, its enactment relies upon embodied actions, such as the sharing of a meal, that convey care through physical co-presence.

Caregiving as a moral experience, according to Kleinman, relies on the 'messy' reciprocal exchange of 'affirmation, acknowledgement, emotion and presence (i.e., meanings)' as well as information $(2013,14)$. Indeed in мотем, sharing was as important as giving; handshakes, conversations and meals taken together were just as valued as sermons delivered or supplies procured. In this way also the young мотем leaders distinguished themselves from the 'big', often corrupt, leaders of larger churches, who zoomed around in fancy cars bypassing their poorer congregants, by their willingness to walk in the dirt along with those they lead. Knowing and sharing the struggles of the place, their particular diseases, social problems, and histories, was essential to providing care. Indeed, many of the leaders' testimonies I witnessed and recorded were carefully crafted to perform a knowledge of a number of specific social issues. From discos and drinking, to orphanhood and AIDs, through narrative they performed their experiences of struggle as a form of cultural capital, and a basis for legitimating the care they now offered others for the same social problems. Thus in мотем, despite the need to dis-identify themselves with many of these markers of a 'spoiled' pre-conversion identity, they used the transformative narrative of conversion to highlight what they had 'passed through'. This passage was an important qualifier for their ability to connect and care for the youth of Kam- 
pala in ways that applied the universality of Christ's compassionate gospel to their own unique set of troubles, to their shared local lifeworlds.

To many of those I spoke to, mobility in youth ministry, such as regular mission's trips to 'the village' (as it was called by the modern, urban Kampalan youth leaders I worked with), allowed them to express this universal love and gain the ministerial legitimacy of being seen as obedient, selfless, and empowered by going to the 'exotic' rural peoples within their own nation. Their aspirations to modernity, such a formative factor in the identity of Kampalan youth, and perhaps even more strongly of evangelical Kampalan youth (Wardell 2015), was evident in much talk of hopes to travel to the United States or United Kingdom, and performance of knowledge of salient western events and individuals. Yet day-to-day at home their success as a 'good' youth leader depended on a local presence and visibility in community networks. Another мотем leader, Pastor Baker explained that

It helps me, when I go out, I know that wherever I go, if I am walking or going, people know me.... So I need to use me name well, not to spoil it. So THAT is one of the things that protects me.

This visibility, he states 'protects' him from the temptation to immoral behaviour. It is also the means through which he models to others the appropriate behaviour of a Christian, which in itself, he asserts, draws them towards themselves choosing to join the family of God. Thus although I have argued for the significance of a sense of global community in shaping the care identities of the мотем leaders, clearly Pastor Baker's performatively-constituted identity is not only discursively shaped by, but directly contingent upon, his embeddedness in local community as well.

\section{CITIZENS, NEIGHBOURS, AND A VERNACULAR COSMOPOLITANISM}

The мотем office sports a bookshelf filled with volumes written by big-name North America pastors, and a laptop filled with pictures of smiling mzungu guests. On the opposite side of the room, Stephen's desk proudly features a small Ugandan flag placed prominently on the main desk, and a gilt-edged framed photo of President Museveni gazing benevolently down from behind. The wall beside is covered with colourful posters for local events, each sporting a Bible verse intended to ring with a powerful and universal significance.

The idea of being in the world, but not of it (deriving from John 17:14-16) is popular and powerful in the мотем community. It this unique context, I have 
argued it is related to the desire to distinguish oneself from the stigmatisation of Ugandan young people as immoral and unhealthy, as discussed earlier. The idea of being 'transformed' by God instead of 'conformed to this world' (from Romans 12:2), is taught in parallel with the John 17 call to become a citizen of nowhere, or at least nowhere 'of this world'. It is a shift not just in locus of identifier, but in scale. Thus in dress and behaviour, the мотем leaders aim to publicly perform their separateness from local forms of belonging, behaviour and morality and instead express their identity as ambassadors of the "Kingdom of Heaven', or the 'Kingdom of God'. This is explained sometimes as being a 'citizen' of heaven, whilst on earth; and it is this language of citizenship which provides a significant metaphorical parallel to the language which circumscribed early discussions of cosmopolitanism. One of the earliest definitions of cosmopolitanism (promoted in particular by Kant) comes from Ancient Greek Philosopher Diogenes' declaration of himself as a 'citizen of the world'. While these identification points - a citizen of 'nowhere' versus 'everywhere' appear somewhat antithetical, I argue that they in fact share a key quality, that of transcendence, which creates convergent consequences for the way care ethics are formulated and applied.

Nussbaum (1997) writes that the cosmopolitan identity hinges on defining oneself primarily in terms of more universal aspirations and concerns. However, Christman argues that when cosmopolitans like Appiah and Nussbaum therefore demand Christianity, as just another 'local affiliation', be subordinated to cosmopolitanisms they are fundamentally misunderstanding Christianity (2010, n.p.). The faith-based youth workers I encountered experienced themselves, sometimes problematically, as having dual citizenship: ultimately and eternally members of God's transcendent spiritual kingdom, but temporarily called to invest themselves meaningfully in the people and communities their identity as Christians impels them to serve and care for. This indeed creates complexity, tension, and paradox, and yet the two have an irrevocable connection; given that it is primarily because of the obligation to care, love and serve others that characterises the Christian care ethic, with its locus in a transcendent global community, that impels them to invest themselves in the people and places around them. Enmeshed in two different levels of moral community, for Ugandan leaders, 'good' may be articulated differently at each layer of identification; between them, discursive meanings may connect and cohere, or they may contrast and conflict. Metaphors provide one key way to make tangible these meanings and values, and shape subjectivities accordingly. In particular, the metaphors of 'family', the 'body', citizenship and the 'kingdom' of God were prominent within the Kampalan community; each one able to create distance or intimacy, belonging, connection or obligation, on or between both local and 
global spheres of sociality.

The Christian identity is marked by a command to love and serve others (John 12:35); a form of discipleship that Christ commanded be taken to 'all nations' (Matthew 28:18). 'Love thy neighbour as thyself' is denoted as his Great Commandment (Mark 12:31). However, to read on from this utterance we see that Jesus is immediately asked by the Teacher of the Law whom he is speaking to, another long-echoing question: 'Who is my neighbour?' It is a question in fact central to the concerns of this chapter, and this special section, around connection, belonging, and care. Christ's answer comes in the form of the now well-known parable of the Good Samaritan; the story of a Jew, robbed, beaten, and left in a ditch only to be ignored by passing Jewish religious officials, and cared for instead by a man from the 'unclean' foreign nation of Samaria. This story is often interpreted as a refocussing of traditional care expectations and obligations into a more universal call of compassion for 'all'. In the New Testament love, compassion, and care are reformulated as embodied and essential expressions of the Christian identity, and the attributes of the recipient less important than their steadfast and nondiscriminatory application. In such ethos it is hard to look past the intended universality of the Kingdom that was to be established.

Suzan cared deeply and often for strangers whom she adopted as daughters. Yet of the many stories Suzan offered about those she had cared for as a youth worker, there was just one that brought tears flooding from her eyes: 'There was one ... in the band. That girl was a village mate ... like I stay here, and she stays across the road. We were friends, we would pray together in the mornings', Suzan explained. This girl, literally a neighbour, one day suddenly stopped attending youth events or meeting Suzan as they usually did to pray and worship together. When Suzan called her to check in, she just said she was busy. Finally Suzan had a dream one night that the girl had become pregnant out of wedlock; an event both morally condemning and with dire consequences for one's life prospects as a young woman, in the context of contemporary Uganda. Suzan sought her out the next day and confronted her on the street. Sure enough, the girl broke down and admitted she was pregnant. Breaking down herself in the telling, Suzan describes standing on the roadside and screaming in distress as her friend confessed.

In Suzan's most heartfelt story, her strongest emotions and compulsions to care were for a girl whom she identified both as friend and neighbour. How does this speak into a discussion on the cosmopolitan ethos within a мотем care ethic? As a transcendent but not strictly universal category of belonging 
and identification, that love commanded among and between believers 'in Christ' is one significant aspect of the wider edict to love. However, believers, for the most part, retain connections and obligations to others outside the family of believers; including relatives, those in physical proximity (the more literal 'neighbours') and the social category of the 'vulnerable' (e.g., widows and orphans). Indeed there are biblical mandates for specific care to all of these.

The study of cosmopolitanism, Josephides argues, should be founded on the idea that 'human beings are both transcendent and social' (2010, 389). The primary argument of her article is that cosmopolitanism is 'an existential condition of humanity, a moral quality that is embedded in everyday social practices' $(2010,394)$. Indeed in Kampala, there is undeniable orientation towards global webs of connection and meaning, and strong precedent for an 'open-ness' and universality of the caring gaze which appears very cosmopolitan, and yet the simultaneous acknowledgement of various planes of commonality and difference exists in the unavoidable projects of connecting, belonging, building with and indeed caring for only a select few put in our path. Vernacular cosmopolitanism is Werbner's $(2006,2008)$ term which somewhat oxymoronically describes this. It captures the dual orientations, commitments, and loyalties people in these communities can have to care and connect with cultural others, even whilst grounding themselves and much of their care labour in geographically and culturally specific locales.

In outlining a variety of theoretical models of care ethics, Engster notes that many models acknowledge that people experience special moral obligations to family and friends, and those we live in close proximity with, but broaden into 'an extensive web of relations that makes caring possible' on a much wider social scale (Engster 2005, 60). Similarly while Appiah's work specifically on cosmopolitan ethical models highlights obligations to strangers, he recognises that this is at all times metred by an awareness of and accounting for difference. Appiah argues that what is needed is a space 'for obligations that are moral and universal and for obligations that are ethical and relative to our thick relations, to our projects - to our identities' $(2006,19)$. In other words, for what he calls a 'necessary' partiality for those we live with. For мотем leaders also, the coexisting local commitments, connections and identities that articulate with and through global ones should in no way disqualify these leaders from being identified as cosmopolitan in their care outlook. Rather it resonates with an image of cosmopolitan care emerging in the real world as layers of connection, obligation, and affect, that extend outwards to both neighbours and strangers to different and varying degrees. 
Christian identities and care practices are complex and multifaceted. The мотем leaders care 'in the name of Jesus'. There is no doubt about their identification with, and sense of belonging in, the Christian faith community (both globally and locally). However seen-and-felt applications and expressions of care they embody extend throughout their local worlds to neighbours and strangers alike, seeking to transcend difference with a cosmopolitan-like ethic that shapes itself around and within their Christian identities. The мотем believer experiences a sense of belonging as both local and global; connection and care enacted through concentric and overlapping circles of obligation and affect. In the мотем case study I have presented, in order to embody the 'good' leader, youth workers had to experience and express considerable knowledge of and commitment to local worlds in the enactment of care, even whilst maintaining a more transcendent, global moral locus in terms of their reasons and motivations for care as both vocation and affect. The metaphors of family are invoked at both levels, to focus and mediate this. The metaphor of citizenship is also used to express the peculiarly awkward orientation to their immediate social world. This latter additionally provides an interesting touchpoint with the most classic definitions of cosmopolitanism, as (Christian) citizens of nowhere take on a resemblance to (Cosmopolitan) citizens of everywhere.

Is it right that we should make this undeniably etic connection between the two ethics? Can these youth leaders be cosmopolitan without necessarily selfidentifying as such? This depends closely on the sense and meaning with which the much-debated term 'cosmopolitanism' is employed. As Beck (2011) explains, Kant's early, normative, philosophical sense of the word implied a conscious and voluntary task, 'clearly the affair of the elite'. However, some instances of its more contemporary use seem to intend, instead, to address the 'unwanted and unobserved side effects' of cosmopolitanisation (Beck 2004) - a mundane process through which individuals are forced to consider the distant other within their moral and practical scope. This of course becomes fuzzy territory that risks regressing to something indistinguishable from the even more well-trod theoretical grounds of 'globalisation'. Nevertheless Beck's observation can be applied to suggest that in contemporary Christian faith communities, even whilst actively cultivating identities and care ethics with considerable difference to those that might be overtly considered cosmopolitan frameworks, elements of the cosmopolitan identity, consciousness and ethic might nonetheless be evident. As such they can be read as the unintended side-effect of global processes that are undoubtedly present both around and within contemporary Christendom. However, they can also be seen as part of a discursive interweaving of global discourses and identities with local ones in response to local identity politics, by strategic and reflexive Christian persons with an 
imperative to both specific and general, affective and practical applications of care in a complex religious modernity.

\section{CONCLUSIONS}

The moral is that which is 'at stake', or in other words, that which can be lost (Kleinman 2006). But it is also about what can be gained. Robbins (2003b) suggests that, moving away from a study of the 'other' or the 'suffering subject', an organising feature of more contemporary anthropological work might be that of the moral subject: an anthropology of the 'good'. Good is not simply perceived, he notes, but actively and imaginatively conceived; a subjective enterprise, to do with the creation of moral selves, but also to do with the fostering of the good in social relations (p.458). In this chapter I have argued the two are tied. The identities or subjectivities into which Christian youth workers are performatively shaping themselves, the 'good' leader, the 'good' Christian', are intimately tied with the realisation of the 'good' in their caring relations with others. Their (universal, Christian) identities both underlie and are reciprocally shaped by their (locally articulated, care-giving) practices.

Cosmopolitanism, viewed as an orientation to the world that can be embedded in individual subjectivities, can thus be theorised as something that can be embodied in and alongside other defining aspects of a subject position, such as religious identity. I have illustrated in this chapter that the relationship of this kind of orientation to the care practices of faith-based communities can come through a convergence of meaning heightened by metaphors such as citizenship, family, and neighbours, that both similarly activate the moral imaginary on a global scale even whilst shaping its practice in 'messy' local worlds. It is care both felt and seen, imagined and believed; and sometimes, both cosmopolitan and Christian.

NOTES

1 Susan Wardell is a lecturer in the Social Anthropology programme, at the University of Otago (Dunedin, New Zealand). Her research interests include emotion and emotionality, mental health and wellbeing, care, non-profit work, morality, religion (esp. Christianity), medical anthropology, disability, Down Syndrome, digital worlds and social media. She also teaches in the areas of death and grief, cultural politics, and the anthropology of evil. Dr. Wardell has a forthcoming ethnographic book entitled: Living in the Tension: Care, Selfhood, and Wellbeing among Faith-based Youth Workers' (Carolina Academic Press - Medical Anthro- 
pology Series, eds. Andrew Strathern \& Pamela Stewart).

Email: susan.wardell@otago.ac.nz

2 Kleinman describes 'ethical discourse' as being based on attempts to create or describe universal codes, while 'moral experience' is practical, local, and particular (Kleinman 2006). Conversely Appiah promotes a view of 'moral obligation' as a universal obligation to all human beings, whilst specifying that 'ethical obligation' in the context of relationship, community, and memory (in Jeffers 2013).

3 'Calling' here refers to a sense of divine intervention or summons on an individual's life, both in bringing them 'to Christ' and into particular roles of service and leadership. It is related to but distinct from secular notions of 'vocation'. Its use among мотем leaders is also culturally specific in an emphasis on collective and general calling to care and serve, rather than individual calling into youth work as a profession, as evident in a New Zealand youth work community for example (Wardell 2015).

4 The emic term 'born-again' functions commonly in Kampala as metonymic shorthand for a practicing evangelical Christian. It is not denominationally specific, but because of its reference to being born again in the spirit, applies to those who have experienced conversion within the charismatic ritual tropes of inviting the presence of the Holy Spirit; 'accepting' salvation, and 'joining' Christ, as a once-off and dramatic shift in subjectivity. The term is both performative and constitutive.

\section{REFERENCES}

Allahyari, R.A. 200o. Visions of Charity: Volunteer Workers and Moral Community. Berkeley: University of California Press.

Appiah, A. 2006. Cosmopolitanism: Ethics in a World of Strangers. New York: WW Norton \& Co.

Austin, J.L. 1962. How to Do Things with Words. Cambridge: Harvard University Press.

Beck, U. 2004. 'Cosmopolitical Realism: On the Distinction between Cosmopolitanism in Philosophy and the Social Sciences'. Global Networks 4(2):131-156.

- 2011. 'Cosmopolitanism as Imagined Communities of Global Risk'. American Behavioural Scientist 55 (10):1346-1361. 
Bennington, G. 1997. Politics and Friendship: A Discussion with Jacques Derrida. Sussex, UK: Centre for Modern French Thought, University of Sussex.

Bielo, J.S. 2007. “The Mind of Christ”: Financial Success, Born-Again Personhood, and the Anthropology of Christianity'. Ethnos 72 (3):316-338.

Christiansen, C. 2011. 'Youth Religiosity and Moral Critique: God, Government and Generations in a Time of AIDs in Uganda'. Africa Development 36 (34):127-146.

Coleman, S. 200o. The Globalisation of Charismatic Christianity: Spreading the Gospel of Prosperity. Cambridge: Cambridge University Press.

Colley, H. 2001. 'Love's Labour Lost? Emotional Labour in Engagement Mentoring With Disaffected Young People’. British Educational Research Association Annual Conference, Leeds, September 13-15.

Csordas, T. 2007. 'Renewal and Re-enchantment: To the Ends of the Earth, To the End of the World'. Paper Presented at the Society for the Anthropology of Religion meetings. Phoenix, AZ, April.

Davies, S. 2012. 'The Management of Faith Based Youth Work' In Critical Issues in Youth Work Management, edited by J. Ord, 140-161. Hoboken: Taylor and Francis.

Elisha, O. 2008. 'Moral Ambitions of Grace: The Paradox of Compassion and Accountability in Evangelical Faith-Based Activism'. Cultural Anthropology 23 (1): 154-189.

Engelke, M. 2002. 'The Problem of Belief: Evans-Pritchard and Victor Turner on 'the Inner Life'. Anthropology Today 18 (6):3-8.

Engster, D. 2005. 'Rethinking Care Theory: The Practice of Caring'. Hypatia $20(3): 50-74$.

Foucault, M. 1988. Technologies of the Self: A Seminar with Michel Foucault. Massachusetts: University of Massachusetts Press.

Gusman, A. 2009. 'HIV/AIDs, Pentecostal Churches, and the "Joseph Generation" in Uganda'. Africa Today 56 (1): 66-86. 
- 2013. 'The Abstinence Campaign and the Construction of the Balokole Identity in the Ugandan Pentecostal Movement'. Canadian Journal of African Studies/La Revue Canadienne Des Études Africaines 47 (2):273-292.

Hockey, J.L. and A. James. 1993. Growing Up and Growing Old: Ageing and Dependency in the Life Course. London: Sage.

Howell, B. M. 2007.'The Repugnant Cultural Other Speaks Back: Christian Identity as Ethnographic "Standpoint"' Anthropological Theory 7 (4):371-91.

Jeffers, C. 2013. 'Appiah's Cosmopolitanism'. The Southern Journal of Philosophy 51(4):488-510.

Josephides, L. 2010. 'Cosmopolitanism as the Existential Condition of Humanity'. Social Anthropology 18 (4):389-395.

Kleinman, A. 2006. What Really Matters: Living a Moral Life amidst Uncertainty and Danger. New York: Oxford University Press.

- 2012. 'Caregiving as Moral Experience'. The Lancet 380 (9853):1550-1551.

- 2013. 'From Illness as Culture to Caregiving as Moral Experience'. New England Journal of Medicine 368 (15):1376-1377.

Larsen, T. 2014. The Slain God: Anthropologist and the Christian Faith. Oxford: Oxford University Press.

Luhrmann, T. 2004. 'Metakinesis: How God Becomes Intimate in Contemporary U.S. Christianity'. American Anthropologist 106 (3):518-528.

Meyer, B. 2004. 'Christianity in Africa: From African Independent to PentecostalCharismatic Churches'. Annual Review of Anthropology 33 (1): 447-474.

мотем. n.d. 'About'. Accessed 15th January 2014 from http://momentoftruths. org/about/.

Muehlebach, A. 2012. The Moral Neoliberal: Welfare and Citizenship in Italy. Chicago: University of Chicago Press.

Nussbaum, M. 1996. 'Patriotism and Cosmopolitanism'. In For Love of Country: Debating the Limits of Patriotism, edited by J.Cohen, 2-17. Boston: Beacon. 
- 1997. 'Kant and Cosmopolitanism'. In Perpetual Peace: Essays on Kant's Cosmopolitan Ideal, edited by J. Bohman and M. Lutz-Bachmann, 25-57. Cambridge: Massachusettes Institute of Technology.

Rapport, N. and S. Stade. 2007. 'A Cosmopolitan Turn - or Return?'. Social Anthropology $15(2): 223-235$.

Richard, A. and D. Rudnyckyj. 2009. 'Economies of Affect'. Journal Royal Anthropological Institute 15(1):57-77.

Robbins, J. 2003a. 'What is a Christian? Notes Toward an Anthropology of Christianity'. Religion 33 (3):191-199.

-2003b. 'Beyond the Suffering Subject: Toward an Anthropology of the Good'. Journal of the Royal Anthropological Institute 19 (3):447-62.

Sercombe, H. 2004. 'Youth Work: The Professionalisation Dilemma'. Youth Studies Australia 23 (4):20-25.

Ward, K. 2004. 'Eating and Sharing: Church and State in Uganda'. Journal of Anglican Studies 3 (1):99-120.

Wardell, S. 2015. 'Living in the Tension: A Cross-Cultural Comparative Study of the Meaning and Management of Care, Self-care, and Wellbeing Across Two Communities of Faith-based Youth Workers'. PhD Thesis in Anthropology. Dunedin: University of Otago.

Werbner, P. 2006. 'Vernacular Cosmopolitanism'. Theory, Culture and Society $23(2-3): 496-498$.

-2008. Anthropology and the New Cosmopolitanism: Rooted, Feminist and Vernacular Perspectives. Oxford: New York.

Wuthnow, R. 1995. Learning to Care: Elementary Kindness in an Age of Indifference. Oxford: Oxford University Press.

- 2012. Acts of Compassion: Caring for Others and Helping Ourselves. Princeton: Princeton University Press. 